\title{
Efficacy and comparison of Shatapushpa Taila Matrabasti with Shatapushpa Churna in Kashtartava (Dysmenorrhoea)
}

\author{
Research Article
}

\section{Meena Shamrao Deogade ${ }^{*}$, Prasad KSR ${ }^{2}$, Tanuja Manoj Nesari³, Deepak Bhati ${ }^{4}$,}

1. Associate Professor, Department of Dravyaguna, All India Institute of Ayurveda, New Delhi. 2. Professor \& Head Department of Panchakarma, LN Ayurved College and Hospital, Bhopal, (M.P). 3. Professor, Head Department of Dravyaguna \& Director, All India Institute of Ayurveda, New Delhi. 4. Senior Medical officer, All India Institute of Ayurveda, New Delhi.

\begin{abstract}
Kashtartava (dysmenorrhoea) affects women's day to day activity and it is most common complaints amongst adolescents. $75 \%$ of adolescents experience pain during menstruation. Dysmenorrhoea can also be associated with nausea, vomiting, diarrhoea, fatigue, blotting abdomen etc. As per Ayurveda Apanavata is the governing force of menstruation; its vitiation gives rise to many gynaecological diseases ( yonivyapad). Kashyapa has mentioned Shatapushpa (Anethum sowa Kurz.) as drug of choice for Artava related problems. So that group A is treated with Shatapushpa churana and group B with Shatapushpa taila matra basti. Shatapushpa Churna and Shatapushpa taila matrabasti showed extremely significant $(\mathrm{P}<0.0001)$ relief in severity of pain however showed significant relief in duration of Pain, Nausea and Breast Tenderness. Overall effect of treatment on Group A showed complete remission $27.27 \%$ whereas Group B showed $63.64 \%$. Statistically both groups are expressed significant results, whereas on the basis of clinical symptoms and overall effect of treatment illustrated in the study the Shatapushpa taila matrabasti is more effective than Shatapushpa churna.
\end{abstract}

Key Words: Kashtartava, Dysmenorrhoea, Shatapushpa taila, Matrabasti, Anethum sowa Kurz.

\section{Introduction}

Ayurveda describes Kashtartava (dysmenorrhoea) under Ashta Artava Vyapad (eight menstrual problems). Because of sedentary life style and food habits this problem increases day by day worldwide. Dysmenorrhea is one of the most common complaints amongst adolescents; it affects the quality of life of many women in their reproductive age. About $25-50 \%$ of adult women and about $75 \%$ of adolescents experience pain during menstruation, with $5-20 \%$ reporting severe dysmenorrhoea (1). Dysmenorrhoea can also be associated with nausea, vomiting, diarrhoea, fatigue, which disturbs routine activities. Dysmenorrhoea is the leading cause of short term school absenteeism. It is associated with a negative impact on social, academic and sports activities of many female adolescent (2).

As per Ayurveda predominant factor for dysmenorrhoea is Vata. Apanavata is the governing force of menstruation; its vitiation gives rise to many diseases like yonivyapad's (vaginal problems) or Artava. Udavartini being one among yonivyapad's in

\section{* Corresponding Author:}

Meena Shamrao Deogade

Associate Professor,

Department of Dravyaguna,

All India Institute of Ayurveda,

New Delhi. India.

Email Id: drmmeena@,rediffmail.com which vitiated Vata moves in reverse direction leading to 'painful menstruation'. The treatment indicated is normalization of Vata. There are several medicines prescribed for said conditions of gynaecological disorders. Shatapushpa (Anethum sowa Kurz.) mentioned as drug of choice in any Artava disease by Kashyapa is selected for present study (3).

It is mentioned in Ayurveda classics that Vasti is an ardha chikitas of Vata diseases, Therefore the Matrabasti of Shatapushpa taila is selected for present study and compared with oral doses form of Shatapushpa.

\section{Materials and Methods}

After getting the Institutional Ethical committee (IEC) Clearance (Ref no. DMIMS (DU)/IEC/ 2017-18/6967) project started. Shatapushpi seeds were purchased from Nagpur market and sent to FRLHT for authentication. The voucher specimen number is FRLHT Col. No. 4578.

Participants with dysmenorrhoea are enrolled through primary questioner on Dysmenorrhoea and selected randomly in both groups. 22 Participants of 18-24 years were included in present study. Group A treated by Shatapushpa churna (Standard) - 10 gm in three divided doses / day for 3 days before commencement of cycle. Whereas Group B treated by Satapushpa taila matrabasti (Test) - $30 \mathrm{ml}$ matarbasti once a day for 3 days before commencement of cycle. Treatment was given 3 consecutive cycles of menstruation for both groups. 
Meena Shamrao Deogade et.al., Efficacy of Shatapushpa Taila Matrabasti with Shatapushpa Churna in Kashtartava

Who are taking Contraceptives or any hormonal treatment and with any Pelvic pathology excluded from the study.

\section{Shatapushpa Taila}

Shatapushpa taila prepared as per reference found in Sharangdhar samhita for taila kalpana. 1 part of Shatapushpa kalka, 4 parts of Til taila and 16 parts of drava (decoction and Godughda) are to be mixed together \& heat on mandagani to prepare Shatapushpa Taila (4).

\section{Shatapushpa churna}

Shatapushpa cleaned, dried and powdered to the fineness of by fine mesh and stored in air tight container for further used.

Clinical assessments were done on the basis of subjective and objective (visual analogue scale (VAS)) parameters.

\section{Subjective parameters}

\section{Duration of pain}

\begin{tabular}{|l|l|}
\hline 24 hours & 1 \\
\hline 48 hours & 2 \\
\hline 72 hours & 3 \\
\hline 96 hours & 4 \\
\hline \multicolumn{1}{|c|}{ Nausea } & 0 \\
\hline No nausea & 1 \\
\hline Before menses to commencement of menses & 2 \\
\hline One day (during menses) & 3 \\
\hline Two days (during menses) & 4 \\
\hline Three to four days (during menses) & \\
\hline
\end{tabular}

\section{Weakness}

\begin{tabular}{|l|l|}
\hline No weakness & 0 \\
\hline Before menses to commencement of menses & 1 \\
\hline One day (during menses) & 2 \\
\hline Two days (during menses) & 3 \\
\hline Three to four days (during menses) & 4
\end{tabular}

\section{Blotting}

\begin{tabular}{|l|l|}
\hline No blotting & 0 \\
\hline Before menses to commencement of menses & 1 \\
\hline One day (during menses) & 2 \\
\hline $\begin{array}{l}\text { Two days (during menses) } \\
\text { Three to four days (during menses) }\end{array}$ & 3 \\
\hline Breast tenderness & 4 \\
\hline No tenderness & 0 \\
\hline Before menses to commencement of menses & 1 \\
\hline One day (during menses) & 2 \\
\hline Two days (during menses) & 3 \\
\hline Three to four days (during menses) & 4 \\
\hline
\end{tabular}

\section{Objective parameters}

Lower abdomen: VAS (visual analogue scale)

Low backache: VAS (visual analogue scale)

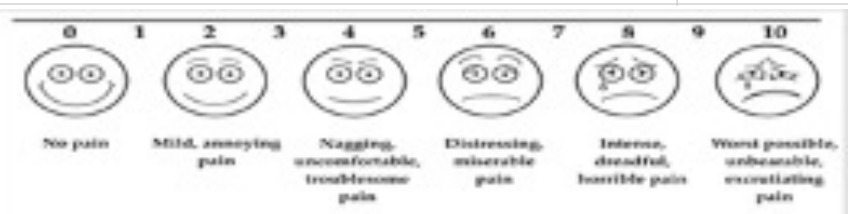

Overall effect of treatment assessed on the basis of subjective and objective parameters as

Complete remission

Moderate improvement

Mild improvement

Unchanged

\section{Observations and Results}

Table 1: Comparison between Group A and Group B Symptoms Group A (Mean)

Group B

\begin{tabular}{|l|c|c|c|r|}
\hline & \multicolumn{2}{|c|}{ (Mean) } & \multicolumn{2}{c|}{ (Mean) } \\
\cline { 2 - 5 } & BT & At & BT & AT \\
\hline $\begin{array}{l}\text { Lower abdomen pain } \\
\text { (Intensity) }\end{array}$ & 7.27 & 3.91 & 7.45 & 2.82 \\
\hline Duration & & & & \\
\hline Nausea & 1.55 & 0.91 & 1.64 & 0.81 \\
\hline Weakness & 0.82 & 0.27 & 0.91 & 0 \\
\hline Blotting & 0.81 & 0.33 & 0.82 & 0.28 \\
\hline Breast tenderness & 1.25 & 0.5 & 1.42 & 0 \\
\hline Low back pain & 0.91 & 0.36 & 0.91 & 0.15 \\
\hline
\end{tabular}

\section{Graph 1: Shows efficacy of Shatapushpa churna}

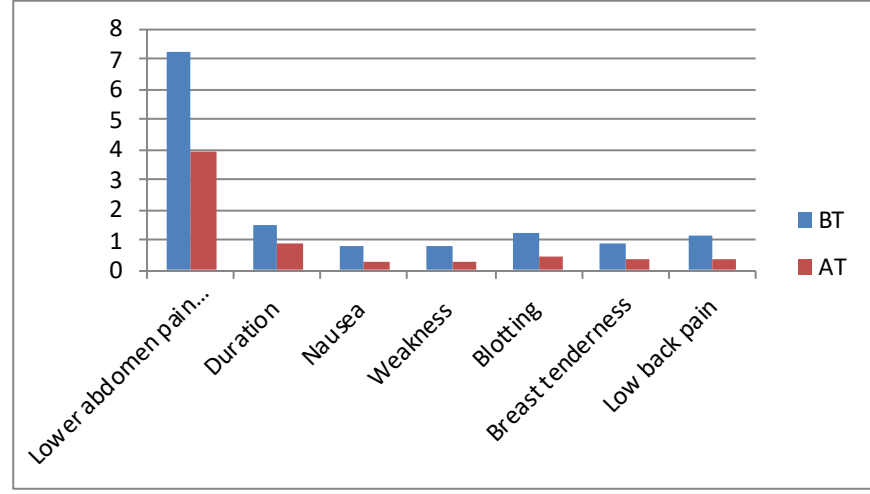

Graph 2: Shows efficacy of Shatapushpa taila matra basti

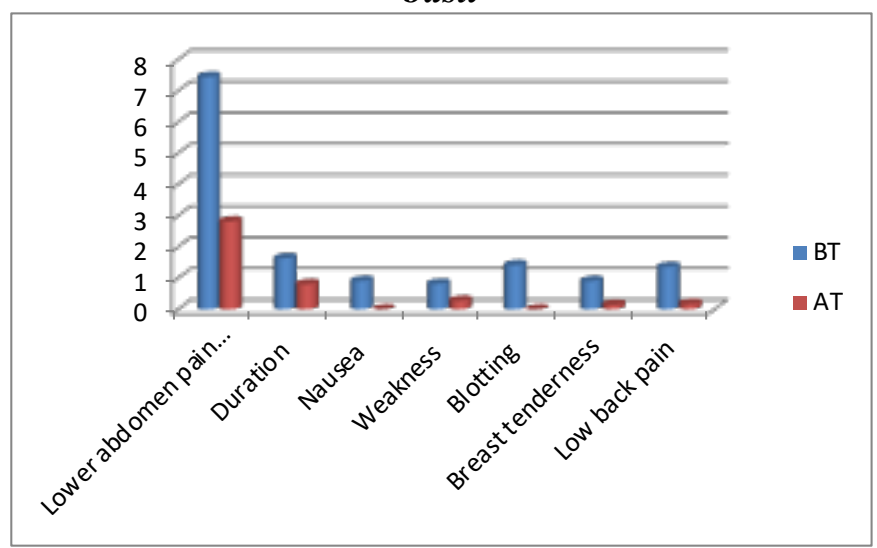


Table 3: Overall effect of treatment

\begin{tabular}{|l|c|c|}
\hline & Group A & Group B \\
\hline Effect of Treatment & \% of patients & \% of patients \\
\hline Complete remission (76-100\%) & $27.27 \%$ & $63.64 \%$ \\
\hline Moderate improvement (51-75\%) & $54.54 \%$ & $45.45 \%$ \\
\hline Mild improvement (26-50\%) & $18.18 \%$ & $0 \%$ \\
\hline Unchanged (0-25\%) & $0 \%$ & $0 \%$ \\
\hline
\end{tabular}

Graph 3: Shows comparative overall result of group A\&B

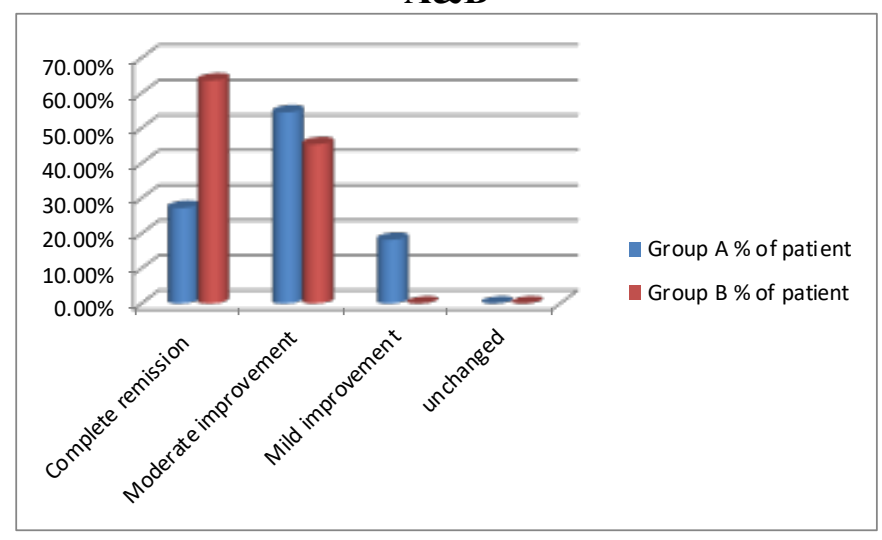

\section{Discussion}

In Ayurveda Dysmenorrhoea i.e. Kashtartava is a symptom of various yoniroga which are described under the context of Yonivyapada. Saruja, sashoola, savedana, saruja, rajah kruchha these terms are used in samhita for kashtartava associated with various yonivyapada. On the basis of Varna, Gandha, Matra, Kala shudhha artava is mentioned and any deviation in these parameters considered about gynaecological problem. Acharya charaka says that pain should not be present during normal menstruation, so the presence of pain during menstruation is abnormal and therefore it requires therapeutic management (5). Vitiated vata is a main cause of the Yoniroga. As pain is the main feature of Kashtartava, so it has strong relation with Vata. In classical text it is explained that due to Vega Dharana of Vata, Mutra and Purisha the Apanavata gets vitiated and it gets Udhravagami i.e. normal Anulomaka Gati of Apana Vayu changes to Pratiloma Gati and this vitiated Vata lifts the Yoni upward and causes obstruction to flow of Raja and Raja comes out with great difficulty with severe Shoola (6). There is a need to prevent or cure this emerging problem. Several herbs are described in Ayurvedic literature for management of kashtartava. Kashyapa describes Shatapushpa (Anethum sowa Roxb.) as nectar for women in various female disorders. He has described its many other medicinal effects in a 
separate chapter called "Shatapushpa Shatavari Kalpadhyaya" in Kalpasthana.

Vata is responsible for its timely excretion through vaginal passage. Thus it appears that basic health of woman governed by Vata dosha. Vata is the main responsible factor, though other doshas only be present as Anubandhi to it. So pain is produced due to vitiation of only vata dosha or in combination with other Doshas. Ayurvedic acharyas specifically mentioned that, in the management of any yoni roga, vata dosha has to be normalized initially. Here the condition characterised with pain and difficulty in expulsion of menstrual blood, also a vataja yoni vyapath known as udavartini (7). The most appropriate treatment modality for vata dushti, is vasti (8). So that basti from Panchakarma offers a ray of hope in kashtartava. Hence Shatapushpa siddha taila matrabasti selected for present study.

$75 \%$ of adolescents experience pain during menstruation, primary dysmenorrhoea occurs in this age group so that 18-24 age group participants were selected in present study. 25 participants were registered in present study, out of that three excluded from study because they have some pelvic pathology. Total 22 participants included which are 18-22 age groups. $9 \%$ of 18 years, $45.45 \%$ of 20 years, $27.27 \%$ of 21 years and $13.63 \%$ of 22 years. A longitudinal study on young women between the ages of 19 and 24 showed that the severity of dysmenorrhea only decreased in women who gave born to children during the previous 5 years, but was unchanged in those who remained nulliparous, or those who had miscarriage or abortion. Another study reported a significant effect of age on the severity of dysmenorrhoea. After adjusting for parity, older women were more likely to experience a decline in the severity of dysmenorrhoea, independent of childbearing. It is observed that the longer the duration of the reported dysmenorrhoeic symptoms (from 2 to 28 years), the greater is the suppression of the woman's hypothalamicpituitary-adrenal axis, as manifested by a reduction in serum cortisol levels (9)

In the present study, the average reduction in clinical symptoms before and after treatment observed in group A treated by Shatapushpa churna as- Intensity of pain 7.27 to 3.91, Duration of pain decreased from 1.55 to 0.91 , Nausea 0.82 to 0.27 , Weakness 0.81 to 0.33 , Bloating 1.25 to 0.51 , Breast tenderness 0.91 to 0.36 , Low backache 1.18 to 0.36 (Table 1, graph 1). Nidhi Garg in 2016 also found almost same results as significant relief in pain and associated symptoms of Kashtartava at her study (10).

Whereas in group B treated by Shatapushpa taila matrabasti show the results as - Intensity of pain 7.45 to 2.82 , Duration of pain decreased from 1.64 to 0.81 , Nausea 0.91 to 0 , Weakness 1.82 to 0.28 , Bloating 1.42 to 0.00 , Breast tenderness 0.91 to 0.00 , Low backache1.36 to 0.18 (Table 1, graph 2). No referral study is available as such study is not undertaken.

Effect on Severity of Pain: Shatapushpa Churna and Shatapushpa taila matrabasti showed extremely significant $(\mathrm{P}<0.0001)$ relief in severity of pain, Hence effect of Shatapushpa Churna and
Shatapushpa taila matrabasti both was better in relieving the severity of pain.

Effect on Duration of Pain: Shatapushpa Churna and Shatapushpa taila matrabasti demonstrated significant $(\mathrm{P}<0.0147)$ and $(\mathrm{P}<0.0261)$ respectively.

Effect on Nausea: Shatapushpa Churna and Shatapushpa taila matrabasti demonstrated significant $(\mathrm{P}<0.0291)$ and $(\mathrm{P}<0.0016)$ respectively.

Effect on Blotting: Shatapushpa Churna and Shatapushpa taila matrabasti demonstrated significant $(\mathrm{P}<0.0053)$ and $(\mathrm{P}<0.0506)$ respectively.

Effect on Nausea: Shatapushpa Churna and Shatapushpa taila matrabasti demonstrated significant $(\mathrm{P}<0.0291)$ and $(\mathrm{P}<0.0016)$ respectively

Effect on Breast Tenderness: Shatapushpa Churna and Shatapushpa taila matrabasti demonstrated significant $(\mathrm{P}<0.0506)$ and $(\mathrm{P}<0.0046)$ respectively.

Effect on Low back Pain: Shatapushpa Churna showed significant $(\mathrm{P}<0.0027)$, wherein Shatapushpa taila matrabasti showed extremely significant $(\mathrm{P}<$ 0.0001) relief in low back pain, Hence effect of Shatapushpa taila matrabasti is better than Shatapushpa Churna in relieving the low back pain.

Overall effect of treatment on Group A showed complete remission $27.27 \%$ whereas Group B showed 63.64\%. Moderate improvement 54.54\%, $45.45 \%$ observed in group A and group B respectively. Mild improvement $18.18 \%$ and $0 \%$ observed in group $\mathrm{A}$ and group B respectively. Unchanged $0 \%$ observed in both groups (Table 3, Graph 3).

\section{Probable Mode of Action of Treatment}

Action of Shatapushpa stated in Ayurveda is Deepana and Pachana. It is not only acts on Jatharagni level but also exhibits its action on Rasadhatwagni. Thus Shatapushpa is helps in the process of proper formation and Rasa for nourishment and develops its Upadhatu - Artava. Having good Vatanulomana property, Shatapushpa Taila regulates the gati (movement) of Praanavata, Vyanavata and Apanavata to maintain all essential functions in co-ordination and normalcy especially in maintaining the normal physiology of the Reproductive System. Thus it regulates the menstruation and flow.

Katu rasa, katu vipaka and ushna veerya of Shatapushpa acts on Ama, and nullifies it. It gives relief from nausea and blotting of abdomen. Shatapushpa Taila is a rich source of phytoestrogens hence the Taila may be suitable in regulating the hormones- LH, FSH, Oestrogen, Progesterone, and Prolactin. Shatapushpa taila matrabasti causes Vatanulomana thereby normalizing Apanavata. Due to that low abdomen pain and low back pain alleviates. Vedanasthapana action of Shatapushpa acts on breast tenderness.

Matra vasti has both local \& systemic affects. Gut is a sensory organ consisting of neural, immune \& sensory detectors and cells, and provides direct input to local (intra mural) regulatory systems and information that passes to CNS or other organs. Vasti may stimulate the enteric nervous system and thus it can influence CNS and all bodily organs. Vasti may act on the neurohumoral system of body by stimulating CNS through 
ENS. It thereby restores the physiology at molecular level. It can also act on the inflammatory substances like prostaglandins and vasopressin etc. The intensity of the menstrual cramps and associated symptoms of dysmenorrhea are directly proportional to the amount of PGF2. Vasti may also help to excrete increased prostaglandins. Visceral afferent stimulation may result in activation of the Hypothalamo-pituitaryadrenal axis and Autonomous nervous system, involving the release of neurotransmitters like serotonin and hormones. Thus, it normalizes the neurotransmitters, hormonal and neural pathways and relieves all the symptom complex emerged as a result of neurohormonal imbalances in the patients of dysmenorrhoea. Spasm caused by vitiated Apana vayu causing obstruction to the flow of menstrual blood is the general underlying pathology. Taila enters into the srotas and removes the sankocha (spasm) by virtue of its sookshma, vyavayi and vikasi i.e. fast spreading nature (11).

\section{Conclusion}

Kashtartava is a symptom of many uterine diseases (Yonivyapada) caused by vitiation of Vata. Shatapushpa taila has added advantage over on Shatapushpa churna oral intake and acts against Vata and brings the Dosha in to equilibrium state. Statistically both groups are expressed significant results, whereas on the basis of clinical symptoms and overall effect of treatment illustrated in the study the Shatapushpa taila matrabasti is more effective than Shatapushpa churna.

\section{References}

1. Boharupi P, Deogade MS. Assessment of Prevalence of Primary Dysmenorrhoea in University Students. International Journal of Ayurvedic Medicine.;2020,11(2):170-4.
2. Proctor M, Murphy PA, Pattison HM, Suckling JA, Farquhar C. Behavioural interventions for dysmenorrhoea. Cochrane database of systematic reviews. 2007(3).

3. Sharma PH. The Kashyapa Samhita of Vriddha Jivaka. R e p rin t. Vara n a s i; C h a u k h a m b h a S a m s k r it Sansthana, 1998. 280p.

4. Srivastava S. Sharngdhar Samhita of Sarngadhar. $3^{\text {rd }}$ Edition.Varanasi; Chaukhamba Orientallie, 2003.215p.

5. Acharya YT. Charaka Samita of Agnivesa. Reprint. Varanasi; Chaukamba Subharati Prakashan, 2006. $643 p$.

6. Hemavathi SK. Management of Dysmenorrhoea with Matra Vasti -A Case Report. IJAAR; 2017 2(2):1601-05

7. Acharya YT. Charaka Samita of Agnivesa. Reprint. Varanasi; Chaukamba Subharati Prakashan, 2006. $635 \mathrm{p}$.

8. Shastri AD. Ashtanga Hridaya of Vagbhata. Varanasi; Chaukamba Subharati Prakashan, 1996, $16 \mathrm{p}$

9. Nobili V, Alisi A, Panera N, Agostoni C. Low birth weight and catch-up-growth associated with metabolic syndrome: a ten year systematic review. Pediatric endocrinology reviews: PER. 2008 ;6(2):241-7.

10. Garg $\mathrm{N}$ and Jain A. Evaluation of efficacy of shatapushpa phala churna in rajakrichrita with special reference to primary dysmenorrhoea,IAMJ. 2016; 4(12):3601-08

11. Bakshi S. A critical review on Dysmenorrhea with reference to Kashtartava and its Ayurvedic management. Journal of Ayurveda and Integrated Medical Sciences (ISSN 2456-3110). 2019 Jul 17;4(3):113-8. 